\title{
3 TRANSPARENCY VERSUS OPACITY IN ABORIGINAL PLACENAMES
}

\author{
Michael Walsh
}

\section{THE BASIC QUESTION: WHAT PROPORTION OF PLACENAMES OF INDIGENOUS ORIGIN ARE TRANSPARENT — IN SOME SENSE?}

This question arose because of the discrepancy I had noticed between a relatively high proportion of transparency of about 66 per cent reported by Dixon (1991:125ff.) for the north Queensland language, Yidiny, compared to the relatively low proportion of transparency of about 20 per cent observed by me in my own work in the Darwin area. This led me to wonder whether there was some kind of norm in the proportion of transparency to opacity in the Aboriginal $^{2}$ placenames of a particular area. In turn this led me to send a query to Peter Sutton and, as I might have expected, he gave me a lengthy and thoughtful reply which indicated that the basic question I had put concealed a range of complications. That reply from Peter Sutton has found its way into his paper in this volume.

Otherwise I have received advice that the pattern across Australia is far from straightforward. Patrick McConvell (pers. comm.) reports that about 80 per cent of placenames in the Victoria River Downs area of the Northern Territory are transparent. Margaret Sharpe (pers. comm.) indicates that most placenames in the Bundjalung area (north-east New South Wales) are transparent but in the Alawa area (Northern Territory) few placenames are transparent. Franca Tamisari (pers. comm.) reports for north-east Arnhem Land that placenames vary in transparency according to a person's age and knowledge.

Comments of this kind suggest that 'transparency' is not a simple notion when applied to Aboriginal placenames. We therefore need to consider a number of types of transparency.

1 This paper was delivered in Canberra at the Placenames of Indigenous Origin: An Interdisciplinary Workshop in association with Australex, the Australian National Placenames Survey and the Australian Language Research Centre, 31 October 1999. It has taken into account comments provided by participants at that workshop.

2 In this paper I prefer 'Aboriginal' to 'Indigenous' because the latter term can also refer to Torres Strait Islanders. My own experience and knowledge overwhelmingly relate to Aboriginal people rather than Torres Strait Islanders. It may be that the observation made here about Aboriginal placenames can also be applied to Torres Strait Islander placenames but I make no claims in that regard.

L. Hercus, F. Hodges and J. Simpson, eds, The Land is a Map: placenames of Indigenous origin in Australia, 43-49.

Canberra: Pandanus Books in association with Pacific Linguistics, 2002.

(c) Michael Walsh 


\section{TOWARDS A TYPOLOGY OF TRANSPARENCY}

\subsection{Clarity - focus on the semantic content of the form of the placename}

The first category deals with the semantic content of the form of the placename. A placename like Camelot or Troy may carry with it a good deal of evocative baggage but this is not evident from the actual forms 'Camelot' and 'Troy'. In the sense intended here a placename like Newtown is rather obviously relatable to the two forms 'new' and 'town'. At first blush a placename like Ashfield might similarly be related to two forms, 'ash' and 'field'. There is a difference between the two placenames in terms of my own knowledge. While the purported bipartite structure of Newtown seems reasonable enough, it also happens to be supported by historical accounts. The other placename, Ashfield, might - for all I know - be an anthroponym, named in order to commemorate someone called Ashfield. While the personal name Ashfield might ultimately be shown to derive from two parts, 'ash' and 'field', that would not be the primary basis by which the place was named. It is a relatively simple matter to check the etymologies for placenames like these from the City of Sydney but it is more likely to be quite a difficult matter for placenames in Aboriginal Australia. Simply asking someone - whether in Sydney or the outback - is no guarantee of an accurate answer. In my experience people who have lived in a place like Newtown for years might not be aware of the structure of the name until it is pointed out to them. For a name like Whitfield, people may guess and happen to be right (in terms of known history); they may recognise part of the name, -field; or they may be unable to say anything about it at all. Here I should point out that there may be differences for Aboriginal and other Australians in expectations about knowledge. An Anglo-Australian may be able to analyse 'new town' but might not expect to know anything more about why it was called Newtown. However, with many (potentially) transparent Aboriginal placenames, speakers expect that someone will be able to analyse the semantic content of the name, perhaps by relating the semantic content to the topography of the place.

Persisting with placenames from Sydney, Maraylya is for me quite opaque in terms of the form of the placename; while for Matraville I can recognise -ville as a recurring partial found elsewhere in Erskineville or Wentworthville. However, it has been pointed out to me that even if Maraylya is opaque, it is connotatively autochthonous. 'Maraylya does carry the baggage of sounding autochthonous, unlike say Cricklethorpe which though unanalysable by most of us will always sound English. This is connotative clarity, or perhaps ethnic provenance clarity - the cultural group of origin is suggested, if not confirmed' (Sutton 2000 ). In sum we have a number of points along a scale of clarity that would include:

$\begin{array}{ll}\text { very clear } & \text { Newtown }=\text { new town } \\ \text { apparently clear } & \text { Ashfield }=\text { ash }+ \text { field/?Ashfield [anthroponym } \\ \text { partly clear } & \text { Matraville = ?Matra }+ \text { ville } \\ \text { unclear } & \text { Maraylya }\end{array}$

Clearly degrees of clarity will depend on such factors as the level of knowledge about the semantic content of the form of the placename. 


\subsection{Recognition - the extent to which the semantic content of a placename is recognisable}

The second category is concerned with the extent to which the semantic content of a placename is recognisable. Notice that I have not restricted myself to the semantic content of the form in this definition. So the recognition of semantic content is potentially broader, relating not just to the form but also to the associations (for places like Camelot and Troy) that are more or less familiar to people. In the arena of Aboriginal placenames one potential line of cleavage in recognisability is that between Indigenous people and analysts. Needless to say the sets do not have to be mutually exclusive. Another contrast is non-analysts vs analysts and this has already been discussed above. A non-analyst might claim that Nightcliff, the suburb of Darwin, is somehow relatable to 'night' and 'cliff'. However, it is known by analysts to be Knight's Cliff originally associated with a certain Mr Knight.

In the Aboriginal sphere native-speaker knowledge of course will vary considerably and folk etymologies may creep in. It may happen that a linguist or other analyst's deductions are in sharp contrast with native-speaker knowledge. And of course a linguist or other analyst's deductions will sometimes be wrong.

The two categories so far described are familiar enough in non-Aboriginal settings in Australia, but the next two categories have features that are particularly relevant to Aboriginal settings.

\subsection{Candour - the extent to which (past) ownership of placenames is acknowledged}

In Aboriginal Australia placenames are owned. A particular name will sit in a particular territory which is owned by a particular Aboriginal group. Languages are also owned by a particular group (see Walsh, 2002) and this adds a complication to Aboriginal placenames. A given place would usually be owned by only one Aboriginal group, but some places have names in two or more languages; so that while the place may be owned by just one group, the names may be owned by more than one group. The category of candour covers the extent to which (past) ownership of placenames is acknowledged.

Let us consider a particular place with three placenames. From the perspective of one group, $\mathrm{X}$, the place has three names from three groups $(\mathrm{X}, \mathrm{Y} \& \mathrm{Z})$ : $\mathrm{X}$ group owns the place and one of its names, while the other two groups each have a name in their own language for that place - for which they do not claim ownership. Meanwhile group Y claims ownership of the place, says it has two names for the place in its own language and acknowledges a third name from the neighbouring group $Z$. In this scenario group $X$ has no place at all. It would be an example of group $Y$ showing a relative lack of candour concerning ownership of that place by group $\mathrm{X}$. This scenario might occur in a situation where group $\mathrm{X}$ in the past was generally acknowledged as the owner of the place in question, but now there are differing viewpoints which will depend on the perspective of the group. The newcomers, group Y, may want to emphasise their ownership of the place in question rather than acknowledge ownership of some kind by another group. Clearly this process is not completed overnight; so there may be a period in which there is considerable debate about the 'true' owners, and problems in the translatability of names can result in the loss of history of ownership (Hercus \& Simpson, this volume). Degrees of candour will affect the relative transparency of a placename for different groups (see also Harvey 1999, esp. 192-194). 


\subsection{Openness - the extent to which constituents of a placename package are open to the wider public}

Finally it is necessary to consider the extent to which information about places in Aboriginal Australia is open to the wider public. I know of a placename in the Darwin area which has become closed in recent years to the extent that most of the 'placename package' (described more fully in §3) is no longer open - including the form. That is to say, for at least some Aboriginal people it is inappropriate to use the placename either in spoken discourse or in its written form. There is also information associated with this placename that should not be referred to in a public setting. Clearly this raises problems for the study of this placename from an outsider's perspective. One point of interest for the study of placenames in Aboriginal Australia is how people refer to a place for which the public use of the 'real' name is proscribed. It would also be interesting to know how widely this phenomenon applies. Among the reasons a placename is proscribed is because it is the personal name of the speaker, or of someone who has passed away, or because it is the place where the speaker was initiated. For example, the English pronunciation of Banka Banka was proscribed after the death of a man called Banka Johnny. The station was then called 'Station' or 'Jinarrinji' after a site near the main Aboriginal camp on that station (Simpson 2000).

\section{PLACENAME PACKAGE}

In the previous section I adopted the rather inelegant expression 'placename package': here it should be unpacked. It seems to me that relevant information about a placename should include at least the following:

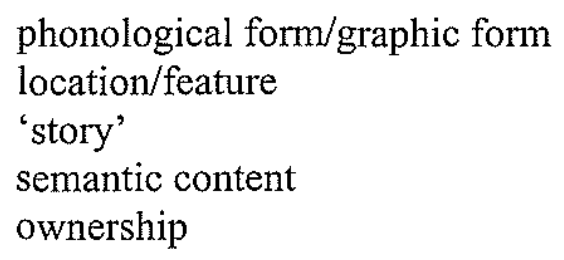

In the previous section I indicated that parts of a 'placename package' could be more or less open (to a wider public). One indication was the proscription of the phonological form/graphic form of a placename. There can be instances where these two forms interact with each other in such a way as to reduce the relative transparency of a placename. One example can be found in a placename somewhat to the west of Darwin which has appeared in graphic form both as Inyarrany and Iynarrayn. In each instance a digraph (ny, yn) is used to represent a palatal nasal. For some Aboriginal people the phonological form has remained constant, while others have adopted a spelling pronunciation so that the third syllable has become two syllables which rhyme with 'Annie'. For those Aboriginal people who know the name only by ear, the spelling pronunciation can be confusing or even scarcely recognisable. The second spelling, Iynarrayn, is more likely to force a three-syllable pronunciation, but the pronunciation still may not correspond with the phonological form that was usual in the past. ${ }^{3}$

This example arose in a land claim setting where much discussion hinges on placenames. For some further examples of phonetic confusion, see Walsh (1999:168-172). 
About location I will be brief. Some placenames can refer to some feature that will establish its location for those in the know: Schebeck (this volume) following Hercus refers to these as 'intermediate names'. Some placenames have narrow scope and wider scope so that the precise location will depend on access to the scope intended in a particular usage. In either case there are degrees of transparency about the precise location to be associated with a particular placename. Associated with a placename's location is the extent to which a topographical feature is referred to in the placename, either implicitly or explicitly. Sutton (2000) observes: 'In the Wik area many placenames explicitly contain a reference to a feature e.g. point-, creek-, well-.' It would be useful to investigate the frequency of appearance of topographic descriptors and their range. We might, for instance, anticipate explicit references to 'point' on the coast but the distribution of such explicit references is yet to be studied in any detail. Also worthy of research attention is the width of the reference: does a particular placename refer to a mountain or to a mountain and the surrounding plain?

The next two components of the placename package, 'story"4 and semantic content, can overlap but it is nevertheless useful to keep them separate. The 'story' can be an account of a figure from the 'Dreamtime' who carried out certain activities at or near the place in question. There may be varying accounts and there may be a desire on the part of Aboriginal people to restrict a 'story'. Harold Koch (pers. comm.) has referred to the central Australian placename Iwupataka (aka Jay Creek) (Walsh, this volume), for which Aboriginal people deliberately promoted a false meaning in order to protect the restricted story that is referred to by this oral name (Strehlow 1971:71) (and see Wilkins, this volume). Semantic content of a placename potentially includes all the associations that may apply to that place. These may include events like a fight or a burial that have taken place in historical times. Either of these would constitute a story about the place but not the 'story'.

The notion of ownership has already been briefly canvassed in $\S 2$ under the heading of 'candour'.

\section{MULTIPLE NAMES FOR A PLACE}

In Aboriginal Australia it is relatively common for a given place to have multiple names. Multiple naming can also be seen in places outside Aboriginal Australia. A city in Turkey is currently known as Istanbul but at one time was known as Constantinople and at another time as Byzantium and each name has its own associations. Here I simply want to provide an overview of some of the multiple naming practices and draw attention to the implications for transparency.

The simplest case is one place having two names. Such doublets can be intralectal or crosslectal. For intralectal doublets where there are two names for the one place in the same lect, ${ }^{5}$ both placenames may be opaque, both transparent, or one opaque and one transparent. In fact the situation can be more complex than this, as exemplified by Sutton (this volume). The same applies to crosslectal doublets where the two names for the one place come from different lects. An intriguing case is provided by Laughren (2000) of a single name within a lect referring to more than one place.

\footnotetext{
4 I use the quote marks around the word 'story' because there are connotations about this word which are not appropriate to accounts of 'Dreamtime' events. Such accounts are not just-so stories for Aboriginal people and certainly they are not fictional.

5 I use the term 'lect' so as to avoid buying into issues concerning dialect, variety and language.
} 
The Nyirrpi story as I know it goes something like this (McConvell, this volume):

The original Nyirrpi name referred to a soakage on Waite Creek where a group of people decided to set up an outstation from Yuendumu in the mid-1970s. For some time people camped out there near that soakage (Nyirrpi is Desert Oak in Luritja and Pintupi, not in Warlpiri by the way). There was a water shortage problem and so water used to be trucked out there from Yuendumu in a water cistern.

The people who go around putting down bores to look for potable water in good supply that merited putting in a bore, eventually found water further south on Waite Creek close to a soakage called Jirtirlparnta. Eventually a bore was put down there and people moved near the bore but kept calling the place Nyirrpi as by that time they were known as the Nyirrpi mob, especially by the White authorities who just called the area Nyirrpi. Between when the people were at the 'real' Nyirrpi and their movement to Jirtirlparnta (alias new Nyirrpi > [present] Nyirrpi or Nyirripi officially) they were camped at another soakage called Walyka. This was also to the north of Jirtirlparnta.

Now people refer to the original Nyirrpi as 'Old Nyirrpi' and to original Jirtirlparnta as 'Nyirrpi' (See McConvell, this volume).

Some places will have more than two names. One example from my own research concerns a place near Darwin called King's Table. Here we have a toponymic triplet with a Larrakia name, a Wagaitj name, and a Kungarakayn name. The question then arises as to which name is used by which people. In my experience (biased by strong association with Larrakia and Wagaitj people) the most commonly used name is the Wagaitj one although many/?most people would acknowledge the place as being owned by the Larrakia. I suspect the Kungarakayn would use the Wagaitj name or the Kungarakayn name but I could only guess about the likelihood of one over the other in a given situation.

It is unclear (to me at least) how multiple naming works and what its function is. We have some case studies (like Schebeck, Sutton and Tamisari, this volume) but we are yet to gain a comprehensive picture for Aboriginal Australia. There are numerous potential questions that might arise. Is there an upper bound on the number of names a particular place might have? As lects decline in usage, are placenames more or less vulnerable? When a lect becomes a lingua franca and expands beyond its original territory, to what extent will places in the new territory gain names from the lingua franca? ${ }^{6}$

\section{TEMPORAL DIMENSION}

Finally, ${ }^{7}$ and briefly, one must consider the robustness of placenames over time. Often enough the time depth for the first known recording of an Aboriginal placename will be quite shallow. For the area near Darwin, Basedow (1906) carried out relatively early recording of placenames in 1905. Checking Basedow's recordings with Indigenous people in 1979 I was able to match a significant number of placenames but some were unrecognisable. Basedow had recorded 47 names of which about 34 are clearly recognisable. Other placenames I recorded in 1979 in this area are no longer recognisable (see Brandl, Haritos \& Walsh 1979:60-67). This is just one instance of placenames becoming less transparent because of the temporal dimension.

\footnotetext{
I am grateful to Pat McConvell for raising the issue of lingua francas.

7 Jane Simpson and Peter Sutton have read and provided valuable comments on a draft of this paper. I am most grateful to them and also to David Nash who responded to a number of queries.
} 


\section{REFERENCES}

Basedow, H., 1906, Anthropological notes on the western coastal tribes of the N.T. and S.A. Royal Society of South Australia Transactions, vol. 31.

Brandl, Maria, Adrienne Haritos and Michael Walsh, 1979, Kenbi Land claim to Vacant Crown Land in the Cox Peninsula Bynoe Harbour and Port Patterson Areas of the Northern Territory of Australia by the Northern Land Council on behalf of the Traditional Owners. Darwin: Northern Land Council.

Dixon, R.M.W., ed., 1991, Words of Our Country: stories, place names and vocabulary in Yidiny, the Aboriginal language of Cairns-Yarrabah region. St Lucia, Qld: University of Queensland Press.

Harvey, M., 1999, Place names and land-language associations in the western Top End. Australian Journal of Linguistics 19(2):161-195.

Hercus, Luise and Jane Simpson, this volume, Indigenous placenames: an introduction.

Laughren, Mary, 2000, Email to Michael Walsh, 17 May 2000.

Schebeck, Bernard, this volume, Some remarks on placenames in the Flinders Ranges.

Simpson, Jane, 2000, Email to Michael Walsh, 31 May 2000.

Strehlow, T.G.H., 1971, Songs of Central Australia. Sydney: Angus \& Robertson.

Sutton, Peter, 2000, Email to Michael Walsh, 29 May 2000.

- this volume, Placenames of the Wik region, Cape York Peninsula.

Tamisari, Franca, this volume, Names and naming: speaking forms into place.

Walsh, Michael, 1999, Interpreting for the transcript: problems in recording Aboriginal land claim proceedings in northern Australia. Forensic Linguistics 6(1):161-195.

Walsh, Michael, 2002, Language ownership: a key issue for Native Title. In John Henderson and David Nash, eds, Linguistic Issues in Native Title Claims Canberra: Native Title Research Series, Aboriginal Studies Press, 230-244. 


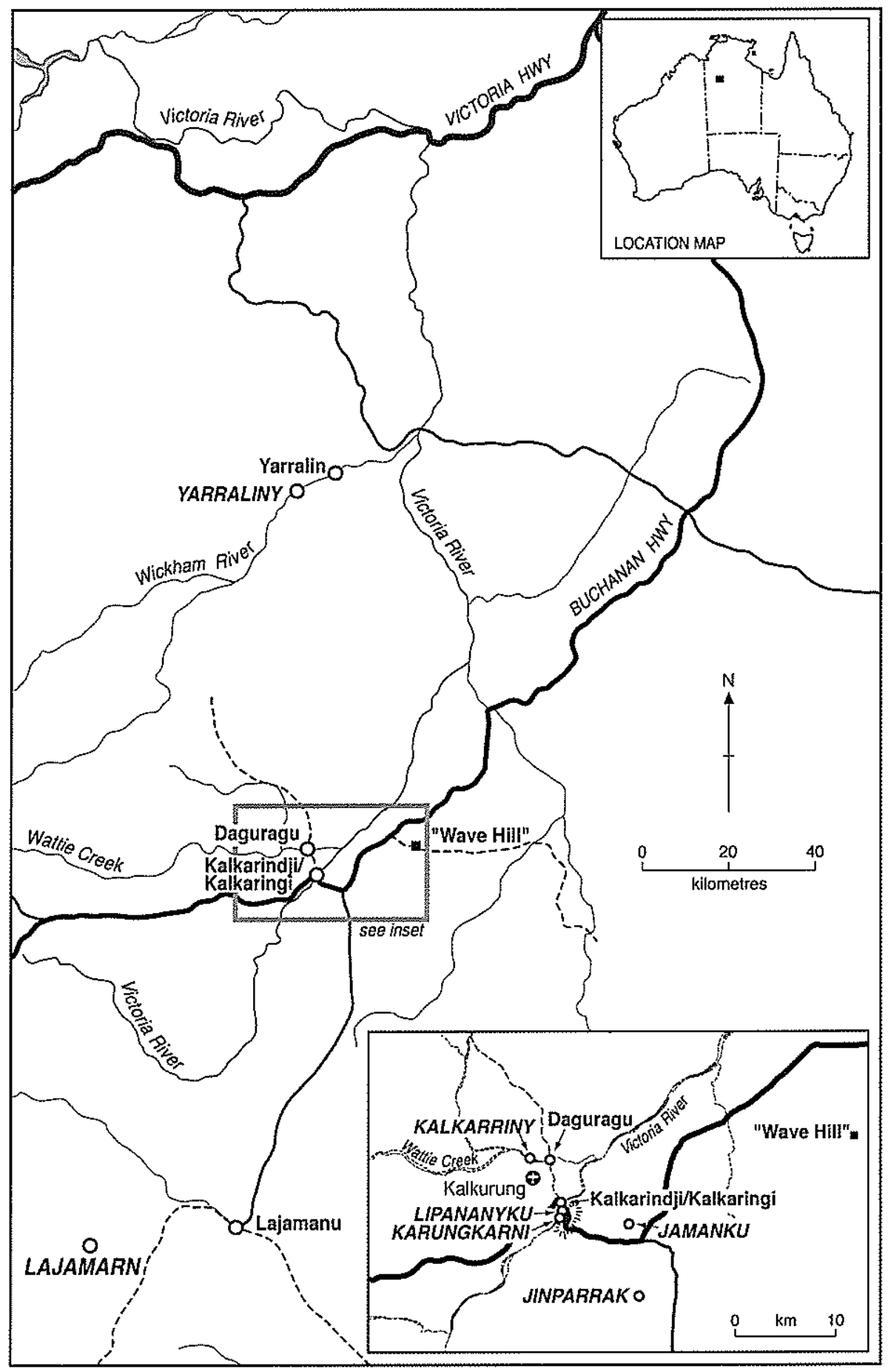

Map 1: Approximate locations of Indigenous and official placenames in the Victoria River District, Northern Territory 